\section{Potential challenge from glia}

\author{
from A.R. Gardner-Medwin
}

THE neurones in our brains are required, as we all know, for the complex information-processing tasks of everyday life. Roughly an equal amount of space in the brain, however, is devoted to glial cells, chiefly astrocytes and oligodendrocytes, whose functions are diverse and poorly understood. Glial cells offer many challenges in understanding the overall function of nervous tissue, just one of which is their intriguing electrophysiological behaviour. Several recent papers ${ }^{1-5}$, including one on page 229 of this issue by Bevan and $\operatorname{Raff}^{1}$, show that glial cells in culture sometimes have hitherto unsuspected membrane characteristics, including high permeability to potassium, higher membrane conductance than resting neurones, direct electrical connections with one another, and the ability to respond metabolically to depolarization induced by local neuronal activity, all of which add to their fascination. How far these properties are characteristic of glial cells in situ is still a matter for conjecture.

The electrophysiological study of glial cells in tissue culture began in 1958 with work of Hild, Ching and Taskai ${ }^{6}$ who showed that morphologically identified glial cells do not display the action potentials that are characteristic of most neurones, yet have resting potentials that are sensitive to potassium. Over the years, with contributions from many people working on both isolated cells and intact tissues, a picture has emerged in which some glial cells have very remarkable properties $^{7-10}$, including probably the most extreme selectivity of membrane permeability for potassium over sodium of all known biological cells.

One aspect that is beginning to be well characterized is the role of glial cells in stabilizing extracellular potassium levels in the nervous system ${ }^{11-15}$. Many questions remain, even in this highly specific area. For example, the relative importance of potassium dispersal through glia and of net uptake into glial cells remains controversial. The principal mechanisms of net uptake are uncertain and the significance of all these mechanisms for normal neural function are largely subjects for speculation. These current issues would tax one's ingenuity enough in designing experiments to settle them, even without the addition of the surprising new data from studies on

\section{Erratum}

In the article by Jonathon Bacon 'Why flying locusts do not crash' (Nature 9 May, p. 94), the fourth paragraph in colunm 3 should begin "The descending neurones make only weak direct connections with flight motor neurones but have strong inputs..."

isolated glial cells in culture.
The special advantages of work in tissue culture are that the cells can be studied in a simplified context and with the widest range of modern cell biology techniques. These include antigenic characterization with monoclonal antibodies and 'patch' electrophysiology, in which a pipette is sealed tightly to the outside of the cell membrane. Because glial membrane conductance is largely a potassium conductance in most preparations, it is gratifying that $\mathrm{K}^{+}$-selective single channels (with, interestingly, a variety of different sizes) have been identified in oligodendrocytes ${ }^{2}$. The observed channels open and shut intermittently, although any channels that are constantly open may perhaps have escaped detection for technical reasons.

IMAGE
UNAVAILABLE
FOR
COPYRIGHT
REASONS

A type 2 astrocyte in culture, stained with fluorescently labelled antibody to glial fibrillary acid protein (courtesy of Dr. J. Cohen).

First of the particularly novel glial characteristics to emerge are sodium-selective ${ }^{3}$ and calcium-selective ${ }^{4}$ conductances, revealed with various pharmacological interventions. Astrocytes treated with barium and tetraethylammonium ions can even produce action potentials, involving $\mathrm{Ca}^{2+}$ channels ${ }^{4}$ and with some resemblance to action potentials of heart muscle. Voltage-dependent sodium ${ }^{5}$ and potassium ${ }^{1}$ conductances, comparable with those normally found in neurones, have now been demonstrated in apparently normal, well-characterized astrocytes in culture (see figure). Despite many electrophysiological studies of cultured astrocytes ${ }^{7}$, such potentials have not previously been reported, so there would seem to be substantial variation in properties between glial cells in different laboratories, and even to a certain extent among cells prepared in a single laboratory, with consistent techniques ${ }^{5}$. The reasons for these differences are obscure, but an impor๑) 1985 Nature Publishing Group tant consideration may be that the cells for which results are illustrated in Bevan and Raff's study ${ }^{1}$ seem to have much higher input resistances $(100-150 \mathrm{M} \Omega$ ) than have been found before (usually $1-10 \mathrm{M} \Omega$ ). It is not clear whether this could be explained by morphological differences, variations in the extent of coupling between cells or aspects of the recording conditions that may affect the membrane conductance. The new findings ${ }^{1-5}$ do show convincingly, however, that some glial cells are capable of producing the molecules, presumably proteins, responsible for various different channels found in membranes.

At least three suggestions can be made as to the possible functional significance of voltage-dependent channels in cultured glial cell membranes. They might have no functional significance at all, appearing only as a consequence of particular culture conditions; they might exist in mature glial cells in vivo and play some physiological role; or they might exist only transiently in glial cells and play some role in the development or maintenance of neurones ${ }^{5}$. Because the channels are opened only when the membrane is depolarized above about $-40 \mathrm{mV}$, they could function solely in conditions leading to extreme glial-cell depolarization.

Such extreme disturbances are known to occur only in two pathological conditions: spreading depression, a condition believed to occur in some migraine attacks ${ }^{16}$, and anoxia. The potasium conductance of glial cells may play a significant role in preventing spreading depression ${ }^{17,18}$, which would indeed be assisted by a conductance increase on depolarization, but none of the studies in vivo has yet revealed a class of glial cells with non-linear conductance ${ }^{7-10}$. The recent studies on cultured glial cells may spur attempts to tackle the substantial technical problems that will be encountered before such cells can be identified with certainity in vivo and distinguished from neurones.

1. Bevan S. \& Raff. M. Nature 315, 229 (1985).

2. Kettenman, H., Orkand, R.K. \& Lux, H.D. Pflügers Arch 400, 215 (1984).

3. Bowman, C.L., Kimelberg, H.K., Frangakis, M.V., Berwald-Netter, Y. \& Edwards, C. J. Neurosci. 4, 1527 (1984).

4. MacVicar, B.A. Science 226, 1345 (1984).

5. Bevan, S., Chiu, S.Y., Gray, P.T.A. \& Ritchie, J.M. $J$. Physiol., Lond. 361, 85P (1985); Proc. R. Soc. B. (in the Physiol.
press)

6. Hild, W., Chang, J.J. \& Tasaki, I. Experientia 14, 220 (1958).

7. Kuffler, S.W., Nicholls, J.G. \& Martin A.R. From Neuron to Brain (Sinauer, Sunderland, Ma., 1984).

8. Sears, T.A. (ed.) Neuronal-Glial Cell Interrelationships, Life Sci. Res. Rep. 20 (Springer, Berlin, 1982).

9. Treherne, J.E. (ed.) J. exp. Biol. 95, (1981).

10. Walz, W. \& Hertz, L. Prog. Neurobiol. 20, 133 (1983).

11. Coles, J.A. \& Orkand, R.K. J. Physiol, Lond. 340, 157 (1983).

12. Dretzel, 1., Heinemann, U., Hofmeier, G. \& Lux, H.D. Expl Brain Res. 46, 73 (1982).

13. Gardner-Medwin, A.R. J. Physiol., Lond. 335, 393 (1983)

14. Newman, E.A. Nature 309, 155 (1984).

15. Walz, W., Wuttke, W. \& Hertz, L. Brain Res. 292, 367 (1984).

16. Current Views on Spreading Depression. Anais Acad. brazil. de Ciencias 56, 371 (1984)

17. Hertz, L. Nature 206, 1091 (1965).

18. Gardner-Medwin, A.R. J. exp. Med. 95, 111 (1981).

A.R. Gardner-Medwin is in the Department of Physiology, University College London, Gower Street, London WCIE 6BT, UK. 